\title{
Genetic divergence and reproductive isolation in the Ochthebius (Calobius) complex (Coleoptera: Hydraenidae)
}

\author{
S Urbanelli \\ Dipartimento di Genetica e Biologia Molecolare, Università La Sapienza, Roma, Italy
}

\begin{abstract}
The reproductive isolation in hydrenid beetles of the Ochthebius complex was studied by analysing gene exchange in natural populations of $O$. quadricollis, Ochthebius sp. A and $O$. brevicollis steinbuehleri collected along the Mediterranean coasts. The ranges of these three species are largely allopatric, but sympatric areas were detected between contiguous taxa, ie, O. quadricollis and Ochthebius sp. A; Ochthebius sp. A and $O$. b. steinbuehleri. Three levels of reproductive isolation and genetic divergence were observed. One level involves extensive intraspecific genetic divergence within the biological species $O$. quadricollis, Ochthebius sp. $A$ and $O$. brevicollis, associated with both physical barriers (eg, sea and sand stretches) and the low dispersal capacity of larvae and adults. The finding of transitional samples between the most differentiated population groups should
\end{abstract}

indicate, however, that there is still some gene flow between the populations of the three taxa. Another level is found between Ochthebius sp. A and O. b. steinbuehleri, whose gene pools appear to be fairly distinct in spite of the fact that reproductive isolation is still incomplete: in their few syntopic sites, some $F_{1}$ hybrids appeared indeed to have lower fitness, since backcrosses or recombinant genotypes were never observed. The final level in the evolution of reproductive isolation (full reproductive isolation) has been achieved by the species $O$. quadricollis and Ochthebius $\mathrm{sp}$. A. No $F_{1}$ or $F_{n}$ hybrids, nor backcrosses were found in their sympatric areas. The relative importance of ecological factors and evolutionary forces in the prevention of gene exchange between taxa are discussed.

Heredity (2002) 88, 333-341. DOI: 10.1038/sj/hdy/6800046

Keywords: genetic divergence; gene flow; hybridisation; hydrenid beetles; introgression; reproductive isolation; sympatric areas

\section{Introduction}

Speciation is central to evolution because of its fundamental role in determining biological diversity. The process of speciation requires the achievement of reproductive isolation. If populations are separated by physical barriers to dispersal, speciation may follow: the achievement of intrinsic reproductive isolation is then an incidental consequence of the accumulation of genetic differentiation (Mayr, 1963). Reproductive barriers may also arise in populations that are not separated by major physical features, hence speciation might begin with genetic diversification in spite of some gene exchange between populations (Bush and Howard, 1986). Between parapatric or sympatric populations where gene exchange is restricted, reproductive isolation can evolve if divergent selection is stronger than gene exchange (Rice and Hostert, 1993; Feder et al, 1997). Although this conclusion has given rise to some controversy, its validity has been supported by the results of recent laboratory experiments and the evidence found in nature (Coyne and Orr, 1997).

In the study of the origin of new species it is then of

Correspondence: S Urbanelli, Dipartimento di Genetica e Biologia Molecolare, Univ. 'La Sapienza', Via dei Sardi no70 00185 Roma, Italy. E-mail: Sandra.urbanelli@uniromal.it

Received 25 June 2001; accepted 25 November 2001 importance to know the level of reproductive isolation among populations, which changes are directly associated with it, under what circumstances such changes occur (allopatry, sympatry), and the relative weight of evolutionary forces in producing these changes. When the divergent populations are parapatric or sympatric, gene exchange can provide evidence of the level of reproductive isolation among populations (Harrison, 1990). Only in the region of contact can gene exchange take place and be quantified by the degree of hybridisation and/or introgression.

The aim of this work was the analysis of reproductive isolation in natural populations of a species complex of the genus Ochthebius. The hydrenid beetles of the genus Ochthebius (Leach, 1815) subgenus Calobius (Wollaston, 1854) are found in coastal rock-pools in the Mediterranean and Macaronesian regions. On the basis of genetic as well morphological differentiation five species were recognised within genus Ochthebius (Calobius). Their geographical ranges are parapatric even if some overlapping areas were observed along the Italian Tyrrhenian coast for O. quadricollis (from western Mediterranean), and Ochthebius sp. A (from the Tyrrhenian, Ionian and Adriatic coasts) and along the Italian Adriatic coast for Ochthebius sp. A and O. brevicollis steinbuehleri (from Adriatic, Greece, Crete and Turkey coasts). The values of genetic differentiation observed between these taxa $\left(D_{N e i}=0.69\right.$ between O. quadricollis and Ochthebius sp. A, and $D_{\mathrm{Nei}}=$ 
0.61 between Ochthebius sp. A and O. b. steinbuehleri) allowed us to hypothesise their present distribution to be related to repeated events of allopatric speciation followed, in many cases, by a range expansion (Urbanelli et al, 1996).

In the present work we analysed the amount of gene exchange among populations of $O$. quadricollis, Ochthebius sp. A and O.b. steinbuehleri, using the distribution pattern of isozyme allele frequencies. The values of intra- and inter-specific genetic diversity and gene flow among populations have been used to identify different levels of reproductive isolation and genetic divergence in natural populations of the three species. On the basis of the results obtained, we have provided a preliminary assessment on the possible ecological factors and evolutionary forces preventing gene exchange between taxa, and the geographical context of the evolution of their reproductive isolation.

\section{Materials and methods}

\section{Samples}

Genetical analysis was conducted on the following taxa of the genus Ochthebius: O. quadricollis, Ochthebius sp. A and $O . b$. steinbuehleri. Specimens were collected from 71 localities along the Mediterranean coasts, including allopatric and sympatric samples (Table 1). The allopatric samples were those already described in Urbanelli et al (1996), whereas most of the sympatric samples were first analysed in the present work.

\section{Allozymic analysis}

Standard horizontal starch gel electrophoresis was performed on single specimens crushed in $0.1 \mathrm{ml}$ distilled water. Fifteen enzymes were analysed in all, encoded by 17 putative loci: glycerol-3P-dehydrogenase (G3pdh), lactate dehydrogenase $(L d h)$, malate dehydrogenase $(M d h-1$, $M d h-2)$, malate dehydrogenase $\left(\mathrm{NADP}^{+}\right)(\mathrm{Mdhp}-1)$, isocitrate dehydrogenase (Idh-1, Idh-2), 6-phosphogluconate dehydrogenase $(6 \mathrm{Pgdh})$, superoxide dismutase (Sod-1), aspartate aminotransferase (Aat-1), hexokinase (Hk-1), esterase (Est-1), leucine aminopeptidase (Lap), aminopeptidase (Pep-1), triose phosphate isomerase (Tpi-1), glucose phosphate isomerase (Gpi), and phosphoglucomutase $(P g m)$. These loci included $\approx 50 \%$ of fast- and $50 \%$ of slow-evolving loci, sensu Koehn and Eanes (1978). The electrophoretic procedures are reported in detail in Urbanelli et al (1996).

\section{Statistical analysis}

Statistical analyses were performed on samples composed of both sexes because no significant differences in allele frequencies were observed between males and females (data not shown). Deviations from Hardy-Weinberg equilibrium were statistically analysed by chisquare, as well as F-statistics (Wright, 1951; Nei, 1978, 1987; Nei and Chesser, 1983). Chi-square contingency test was performed to detect significant differences in allele frequencies among samples (Sokal and Rohlf, 1981).

Genetic divergence among conspecific populations was evaluated through Wright's F-statistic, $F_{\mathrm{ST}}$ coefficients analysed using the procedure by Weir and Cockerman (1984). $F_{\mathrm{ST}}$ is the correlation between random gametes within populations relative to the gametic array of the total populations and reflects heterogeneity among populations.

Gene flow was estimated from the $F_{\mathrm{ST}}$ values using the relationship $F_{\mathrm{ST}}=1 /(4 N m+1)$, where $N$ is the effective size of an isolated, panmictic population, and $m$ is the proportion of migrant individuals in a population (Wright, 1931; Slatkin, 1985).

To evaluate hybridisation and introgression phenomena in the contact zones, a genetic hybrid index score (HIS) was calculated for each specimen, based on the procedure adopted in most studies on animal hybrid zones (Patton et al, 1979; Sage et al, 1986). The index was computed for each specimen by assigning for each locus a score from +1 to -1 to the alleles that characterise the 'pure' taxa. The characteristic alleles of O. quadricollis and $O$. b. steinbuehleri were assigned +1 ; those of Ochthebius $\mathrm{sp}$. A were assigned -1 . The character index score of an individual represented the algebraic sum of its score over all loci surveyed. Since all considered loci had unique alleles in the three taxa, the score of an individual could range from +16 to -16 in the comparison between $O$. quadricollis and Ochthebius sp. A, and from +10 to -10 between O. b. steinbuehleri and Ochthebius sp. A. To visualise the procedure see Table 3 . This method provides a good way to visualise the genotypic composition of a population and hence the level of isolation between taxa.

\section{Results}

\section{Genetic divergence and gene exchange between Ochthebius species}

Analysis of conspecific populations: The allele frequencies of some representative populations within O. quadricollis, Ochthebius sp. A and O. brevicollis steinbuehleri (subspecies of O. brevicollis), are given in Urbanelli et al (1996).

A measure of population diversity was provided by the standardised variance of allele frequencies $\left(F_{\mathrm{ST}}\right.$ values) with a chi-square contingency analysis of heterogeneity. Significant values of genetic diversity among all conspecific populations were observed, dependent on significant differences in allele frequencies at the loci $L d h$, Mdh-1, Mdhp-1, Idh-1, Idh-2 and Gpi among populations of O. quadricollis, at the loci Mdhp-1 and $6 P g d h$ among populations of Ochthebius sp. A, and at the loci $6 P g d h$, Aat-1 and Gpi among populations of O. b. steinbuehleri (Table 2). The electrophoretic patterns at these loci showed a continuous variation indicating the presence of several main population groups within the three species.

In O. quadricollis high frequencies of $I d h-1^{100}$ and $G p i^{100}$ were found in northern Spain, southern France, Liguria, Tuscany, Corsica and Sardinia populations (group I), as compared with those from Calabria, Sicily, Malta and Tunisia (group III), where alleles $I d h-1^{102}$ and $G p i^{117}$ prevail. In the populations of Tuscany (Elba island), Malta and Tunisia a third allele, $G p i^{110}$, is the most common. Tunisia and Malta populations reveal the presence of a further allele, $\mathrm{Gpi}^{88}$. The samples from Latium, Circeo and Ponza island (group II) showed a high frequency of alleles $I d h-1^{102}$ and $G p i^{117}$, more frequent in the third group (Figure 1). In these samples $M d h p-1^{105}$ is nearly fixed, while it does not reach $10 \%$ in the other populations of O. quadricollis (Urbanelli et al, 1996). 
Table 1 Samples of Ochthebius quadricollis $(\bullet)$, Ochthebius sp. A $(\triangle)$ and O. brevicollis steinbuehleri $(\bullet)$

from Mediterranean regions

\begin{tabular}{|c|c|c|c|c|c|}
\hline \multicolumn{2}{|c|}{ Reference and localities } & \multirow{2}{*}{$\begin{array}{l}n \\
62\end{array}$} & \multicolumn{2}{|c|}{ Reference and localities } & \multirow{2}{*}{$\begin{array}{l}n \\
77\end{array}$} \\
\hline 1 & Llanca (Spagna) $\bullet$ & & 38 & Scilla, Reggio Calabria (Calabria) $\triangle$ & \\
\hline 2 & Marseille (S France) & 54 & 39 & Capo Rizzuto, Cosenza (Calabria) $\triangle$ & 57 \\
\hline 3 & Le Levandou, Toulon (S France) $\bullet$ & 41 & 40 & Rocca Pina, Ajaccio (Corsica) & 42 \\
\hline 4 & Ile Du Port Cros, Toulon (S France) & 38 & 41 & S. Ambrogio, Ajaccio (Corsica) & 35 \\
\hline 5 & La Gaillarde (France) & 47 & 42 & S. Teresa di Gallura (Sardinia) & 32 \\
\hline 6 & Esterel, Saint Raphaël (S France) $\bullet$ & 26 & 43 & Pitzo Idu, Alghero (Sardinia) & 33 \\
\hline 7 & Bergeggi, Savona (Liguria) & 30 & 44 & Cala Gonone, Nuoro (Sardinia) & 63 \\
\hline 8 & Zoagli, Genova (Liguria) & 35 & 45 & Panarea Island, Eolie (Sicily) $\bullet$ & 30 \\
\hline 9 & Fiascherino, La Spezia (Liguria) & 39 & 46 & Cefalu', Palermo (Sicily) & 48 \\
\hline 10 & Castiglioncello, Livorno (Tuscany) & 35 & 47 & Marettimo Island, Egadi (Sicily) $\bullet$ & 36 \\
\hline 11 & Populonia (Tuscany) & 82 & 48 & Favignana Island, Egadi (Sicily) $\bullet$ & 71 \\
\hline 12 & Piombino (Tuscany) $\diamond \Delta$ & 80 & 49 & Siracusa (Sicily) & 65 \\
\hline 13 & Elba Island (Tuscany) & 59 & 50 & Cirkewwa (Malta) & 57 \\
\hline 14 & Punta Ala, Grosseto (Tuscany) $\triangle$ & 37 & 51 & Bizerte (Tunisia) & 58 \\
\hline 15 & Talamone, Grosseto (Tuscany) $\triangle$ & 39 & 52 & Taranto (Apulia) $\triangle$ & 102 \\
\hline 16 & Giglio Island, Grosseto (Tuscany) $\diamond$ & 67 & 53 & Gallipoli (Apulia) $\triangle$ & 110 \\
\hline 17 & Argentario, Grosseto (Tuscany) $\triangle$ & 44 & 54 & S. Maria di Leuca, Lecce (Apulia) $\triangle$ & 130 \\
\hline 18 & Burano Island, Grosseto (Tuscany) $\triangle$ & 37 & 55 & Roca Vecchia, Lecce (Apulia) & 256 \\
\hline 19 & Circeo, Latina (Latium) $\bullet$ & 70 & 56 & Pantanagianni, Brindisi (Apulia) $\triangle$ & 201 \\
\hline 20 & Ponza Island, Latina (Latium) $\diamond$ & 101 & 57 & Diana Marina, Brindisi (Apulia) & 144 \\
\hline 21 & Sperlonga, Latina (Latium) $\triangle$ & 132 & 58 & Forcatella, Brindisi (Apulia) $\triangle \odot$ & 90 \\
\hline 22 & Scauri, Latina (Latium) $\triangle$ & 103 & 59 & Marfa, Brindisi (Apulia) $\triangle \odot$ & 127 \\
\hline 23 & Sorrento, Salerno (Campania) $\triangle$ & 50 & 60 & Egnazia, Brindisi (Apulia) $\triangle$ & 94 \\
\hline 24 & Nerano, Salerno (Campania) $\diamond \Delta$ & 62 & 61 & Molfetta, Bari (Apulia) & 65 \\
\hline 25 & Erchie, Salerno (Campania) $\triangle$ & 109 & 62 & Peschici, Foggia (Apulia) & 165 \\
\hline 26 & Ascea, Salerno (Campania) $\triangle$ & 98 & 63 & Tremiti Islands (Apulia) & 34 \\
\hline 27 & Palinuro, Salerno (Campania) $\diamond \Delta$ & 77 & 64 & Ancona (Marche) & 100 \\
\hline 28 & Camerota, Salerno (Campania) $\diamond \Delta$ & 162 & 65 & Trieste (Venezia Giulia) & 40 \\
\hline 29 & Sapri, Salerno (Campania) $\diamond \triangle$ & 106 & 66 & Dubrovnik (Croatia) & 30 \\
\hline 30 & Maratea, Potenza (Basilicata) $\diamond \triangle$ & 98 & 67 & Monenvasia (Greece) & 29 \\
\hline 31 & Isola di Dino, Cosenza (Calabria) $\diamond \Delta$ & 196 & 68 & Agios Nikolaos (Crete) & 42 \\
\hline 32 & S. Nicola, Cosenza (Calabria) $\diamond \triangle$ & 144 & 69 & Castellorizo Island (E Greece) & 28 \\
\hline 33 & Cirella, Cosenza (Calabria) $\diamond \triangle$ & 123 & 70 & Ghiorgos Island (E Greece) & 37 \\
\hline 34 & Diamante, Cosenza (Calabria) $\diamond$ & 67 & 71 & Olu Deniz (S-O Turkey) & 25 \\
\hline 35 & Pizzo, Cosenza (Calabria) $\bullet$ & 89 & & & \\
\hline 36 & Briatico, Cosenza (Calabria) $\bullet$ & 44 & & & \\
\hline 37 & Palmi, Reggio Calabria (Calabria) $\triangle$ & 53 & & & \\
\hline
\end{tabular}

$n=$ number of specimens studied.

Similarly, the pattern of geographic differentiation of Ochthebius sp. A showed three main population groups on the basis of different alleles at loci Mdhp-1 and $6 P g d h$ : the first includes samples from Tuscany and is characterised by the combination of allele $M d h p-1^{107}$ and $6 P g d h^{98}$; the second is composed by samples from Tuscany, Latium, Campania, and Calabria, where alleles Mdhp- $1^{100}$, $6 P g d h^{92}$ and $6 P g d h^{98}$ are the most common. Remarkably, one Tuscan population (Punta Ala) included in this group showed a high frequency (40\%) of allele Mdhp- $1^{107}$, typical of the populations of the first group. The third group of Ochthebius sp. A populations, which includes samples from Apulia, is characterised by the combination $M d h p-l^{100}$ and $6 P g d h^{92}$, and is nearly fixed (Figure 2).

In O. b. steinbuehleri, two main population groups were found: group I includes Adriatic, Cretan and Greek (Monemvasia) populations, characterised by alleles $6 \mathrm{Pgdh}^{80}$ and $\mathrm{Gpi}^{108}$; group II includes samples from Greece (Kastellorizo and Ghiorgos islands) and southwestern Turkey, with alleles $6 P g d h^{80}$ and $G p i^{102}$ (Figure 3).

When the populations of the three species were divided in the main groups mentioned above, no significant genetic diversity was observed. Indirect estimates of gene flow $(\mathrm{Nm})$ were obtained from standardised allele variance $\left(F_{\mathrm{ST}}\right)$ for O. quadricollis, Ochthebius sp. A and O. $b$. steinbuehleri populations (Table 2). As expected, low levels of gene flow were obtained for each taxon when all populations were included $(\mathrm{Nm}=0.28,0.30$, and 0.18 , respectively). Much higher values of $\mathrm{Nm}$ were found when only the main population groups were considered $(\mathrm{Nm}=1.35$ for O. quadricollis from northern Spain, southern France, Liguria, Tuscany, Corsica and Sardinia; $\mathrm{Nm}$ $=12.65$ for Ochthebius sp. A from Tuscany; $N m=8.34$ for O. b. steinbuehleri from Adriatic coasts, Croatia and Crete). Group splitting highlights the role of populations such as Punta Ala, Elba island or Circeo and Ponza island as 'links' between the detected groups. They show that some gene exchange among them could still be possible.

Analysis of sympatric populations between species Location of the contact zones: Several sympatric sites were detected in Tuscany (11, 12 and 16), Campania (24, 2729), Basilicata (30) and Calabria (31-34) between O. quadricollis and Ochthebius sp. A, and in Apulia $(58,59)$ between Ochthebius sp. A and O.b. steinbuehleri. To evaluate the reproductive isolation in the contact zones, a character index score was calculated on the basis of the diagnostic loci within each group. G3pdh, $M d h-1$, Idh-2, 
Table $2 F_{\mathrm{ST}}$ estimates and number of migrants $(\mathrm{Nm})$ for Ochthebius species population subdivisions

\begin{tabular}{|c|c|c|c|c|c|c|c|c|}
\hline \multirow[t]{2}{*}{ O. quadricollis } & \multicolumn{7}{|c|}{$F_{\mathrm{ST}}$} & \multirow[t]{2}{*}{$N m_{\left(F_{\mathrm{ST}}\right.}$} \\
\hline & $L d h$ & $M d h-1$ & Mdhp-1 & $I d h-1$ & Idh-2 & Gpi & All & \\
\hline All populations & $0.527^{*}$ & $0.287^{*}$ & $0.715^{*}$ & $0.307^{*}$ & $0.595^{*}$ & $0.670^{*}$ & $0.474^{*}$ & 0.28 \\
\hline $\begin{array}{l}\text { Group I } \\
\text { N Spain, S France, Liguria, } \\
\text { Tuscany (Elba island and } \\
\text { Castiglioncello), Corsica and Sardinia }\end{array}$ & 0.086 & 0.018 & 0.020 & $0.113^{*}$ & 0.042 & $0.388^{*}$ & 0.156 & 1.35 \\
\hline $\begin{array}{l}\text { N Spain, S France, Liguria, } \\
\text { Tuscany (Castiglioncello), Corscia and } \\
\text { Sardinia }\end{array}$ & 0.084 & 0.018 & 0.021 & 0.107 & 0.042 & 0.099 & 0.091 & 2.48 \\
\hline $\begin{array}{l}\text { Group II } \\
\text { Circeo and Ponza Island }\end{array}$ & - & - & - & - & - & 0.017 & 0.014 & 17.38 \\
\hline $\begin{array}{l}\text { Group III } \\
\text { Tunisia, Malta, Calabria and Sicily }\end{array}$ & $0.250^{*}$ & $0.285^{*}$ & 0.023 & 0.015 & $0.345^{*}$ & $0.450^{*}$ & 0.244 & 0.78 \\
\hline Calabria and Sicily & 0.172 & - & - & 0.017 & $0.391^{*}$ & 0.088 & 0.179 & 1.14 \\
\hline Ochthebius sp. A & Mdhp-1 & $6 P g d h$ & & & & & All & $N m_{\left(F_{\mathrm{ST}}\right)}$ \\
\hline All populations & $0.708^{*}$ & $0.575^{*}$ & & & & & $0.452^{*}$ & 0.30 \\
\hline $\begin{array}{l}\text { Group I } \\
\text { S Tuscany (Talamone, Argentario and } \\
\text { Burano island) }\end{array}$ & - & 0.017 & & & & & 0.019 & 12.65 \\
\hline $\begin{array}{l}\text { Group II } \\
\text { Tuscany (Punta Ala), Latium, Campania } \\
\text { and Calabria }\end{array}$ & 0.150 & 0.195 & & & & & 0.105 & 2.12 \\
\hline Latium, Campania and Calabria & 0.026 & 0.159 & & & & & 0.066 & 3.52 \\
\hline $\begin{array}{l}\text { Group III } \\
\text { Apulia }\end{array}$ & 0.023 & 0.117 & & & & & 0.055 & 4.35 \\
\hline O. brevicollis steinbuehleri & $6 P g d h$ & Aat-1 & Gpi & & & & All & $N m_{\left(F_{\mathrm{ST}}\right)}$ \\
\hline All populations & $0.363^{*}$ & $0.534^{*}$ & $0.859^{*}$ & & & & $0.567^{*}$ & 0.18 \\
\hline $\begin{array}{l}\text { Group I } \\
\text { Adriatic coast of Italy, Croatia, Crete } \\
\text { and Greece (Monemvasia) }\end{array}$ & 0.915 & 0.077 & 0.016 & & & & 0.333 & 0.50 \\
\hline $\begin{array}{l}\text { Adriatic coast of Italy, Croatia and } \\
\text { Crete }\end{array}$ & 0.022 & 0.075 & 0.015 & & & & 0.029 & 8.34 \\
\hline $\begin{array}{l}\text { Group II } \\
\text { E. Greece (Castellorizo and Ghiorgos } \\
\text { islands), SW Turkey }\end{array}$ & 0.031 & - & 0.013 & & & & 0.009 & 26.15 \\
\hline
\end{tabular}

$* P<0.001$.

6Pgdh, Aat-1, Pep-1, Gpi and Pgm were diagnostic between O. quadricollis and Ochthebius sp. A. Idh-2, 6Pgdh, Aat-1, Pep-1 and Gpi showed alternative alleles between Ochthebius sp. A and O. b. steinbuehleri (Table 3).

Extent of hybridisation and introgression: Character index scores for the samples from sites 11, 12, 16 and sites 24, 27-34 of central and southern Italy are shown in Figure 4. In these sites inhabited by O. quadricollis and/or Ochthebius sp. A neither $\mathrm{F}_{1}$ hybrids nor backcrosses were found, while some individuals with genotypes containing characteristic alleles of both species were observed. In the sites 12 and 24-33 the specimens clustered at the two ends of the histograms, while the samples from sites 11, 16 and 34 were composed of specimens genetically identified as $O$. quadricollis and by few introgressed specimens.
In the allopatric populations we never found genotypes containing characteristic alleles of both species: allopatric samples of O. quadricollis and Ochthebius sp. A were only composed of specimens with score +16 and -16 , respectively.

Locations 24 and 27-34 were sampled again between 1990 and 1993 to analyse the temporal pattern of spatial distribution of O. quadricollis and Ochthebius sp. A in the contact zone, and to confirm the apparent lack of hybridisation. Despite some variation in the proportion between the two species, the sympatry between the two taxa was stable. No $F_{1}$ hybrids, backcrosses or recombinant genotypes (ie, genotypes indicating gene exchange) were ever observed. The introgressed genotypes observed were detected only at loci Mdh-1, 6Pgdh, Gpi and Pgm in O. quadricollis and Ochthebius sp. A and are reported in Table 


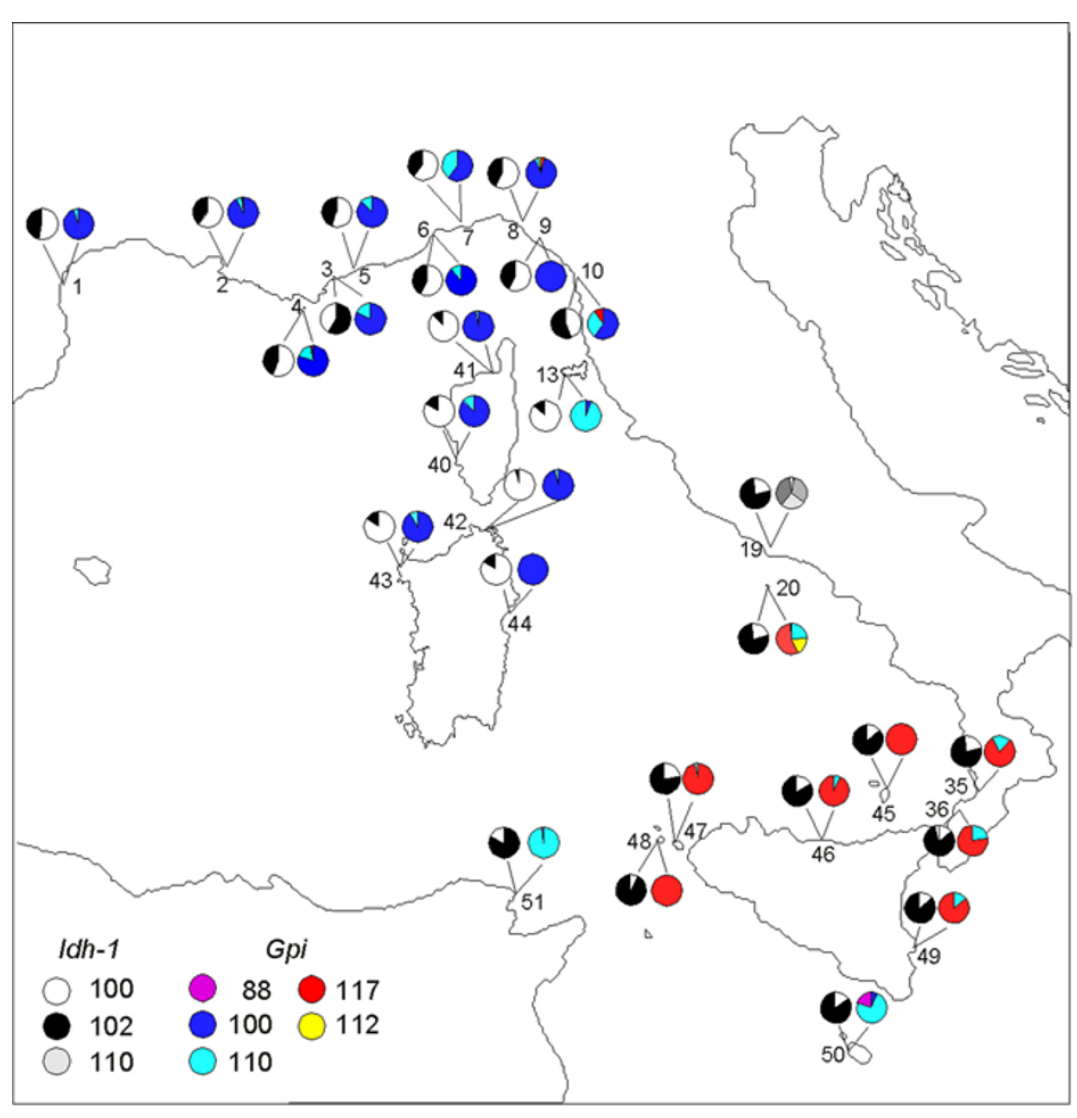

Figure 1 Geographic variation of allele frequencies at loci Idh-1 and Gpi in allopatric populations of Ochthebius quadricollis. For sample geographical origin see Table 1.

4. Moreover different patterns of introgression were observed at these loci, higher for $M d h-1$ and $6 P g d h$ in both species and remarkably lower for Pgi and Pgm. Such patterns are similar for all the localities in all the sampling years, regardless of geographical distance. This shows that alleles at certain enzyme loci can penetrate in a foreign genome more easily than others (Bert and Harrison, 1988). No significant variation was detected by a chi-square analysis between the average values of introgression observed for the two species in time (Table 4). Genotype frequencies at loci $M d h-1,6-P g d h, G p i$ and $P g m$ in the Tyrrhenian contact zone were always in agreement with Hardy-Weinberg's expectations, ie, there was neither deficit nor excess of heterozygotes (data not shown).

The contact zone along the Adriatic coast is very limited at present (Figure 4). The sample from site 58 turned out to be composed of $90 \%$ O. b. steinbuehleri and $10 \%$ Ochthebius sp. A. Neither $\mathrm{F}_{1}$ hybrids nor introgressed specimens were found. In site 59, a few hundred metres away, Ochthebius sp. A was observed in a proportion of $81 \%$ against $16 \%$ of $O$. b. steinbuehleri. Here $\mathrm{F}_{1}$ hybrids were $3 \%$, while no backcrosses or recombinant genotypes nor introgressed specimens were detected.

\section{Discussion}

The genetic studies on population samples of O. quadricollis, Ochthebius sp. A and O. b. steinbuehleri provided evidence of three levels of genetic divergence and reproductive isolation in the Ochthebius (Calobius) species.
These biological species showed extensive intraspecific genetic differentiation. High genetic differentiation was indeed observed among some major population groups within the species, as revealed by significant $F_{\mathrm{ST}}$ values and low levels of gene flow ( $\mathrm{Nm}$ ) among them (Table 2). Conversely, low $F_{\mathrm{ST}}$ values and high levels of gene flow were observed when the populations within these groups were compared. Transitional samples, ie, Elba and Punta Ala populations, have been found between the most differentiated population groups of O. quadricollis and Ochthebius sp. A, respectively (Figures 1 and 2), indicating that some gene flow is still occurring between them. Presumably characterised by a low dispersal capability, Ochthebius beetles spend the larval and adult stages of their life cycle in ponds on rocky shores. These habitats are ubiquitously but irregularly distributed along the coasts of the Mediterranean basin (Beier, 1956; our observations). The levels of subdivision observed in the populations of these three species are not only related to the large geographical distances, but may also be the result of unsuitable habitats such as sea or sand stretches. Good examples are the samples of $O$. quadricollis from northern Spain, southern France, Liguria, Tuscany, Corsica and Sardinia compared with those from Calabria and Sicily; the populations of Ochthebius sp. A from Tuscany compared with those of Adriatic Apulia, and the samples of O.b. steinbuehleri from Greece and south-western Turkey compared with those from the Adriatic coast. Nevertheless, there are apparently impassable barriers between some populations within the main groups as well, eg, French populations of $O$. quadricollis are separ- 


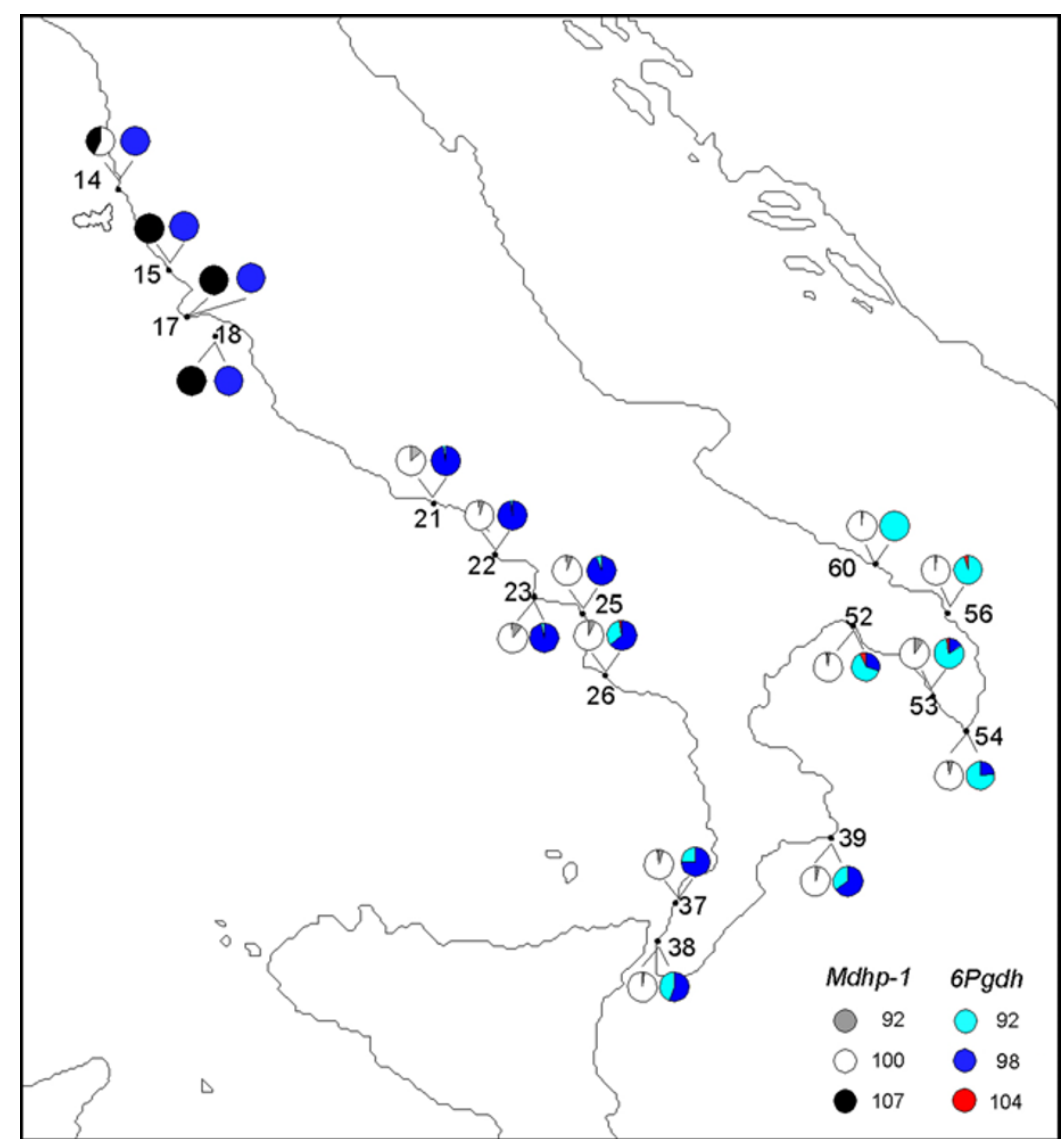

Figure 2 Geographic variation of allele frequencies at loci Mdhp-1 and $6 P g d h$ in allopatric populations of Ochtebius sp. A. For sample geographical origin see Table 1.

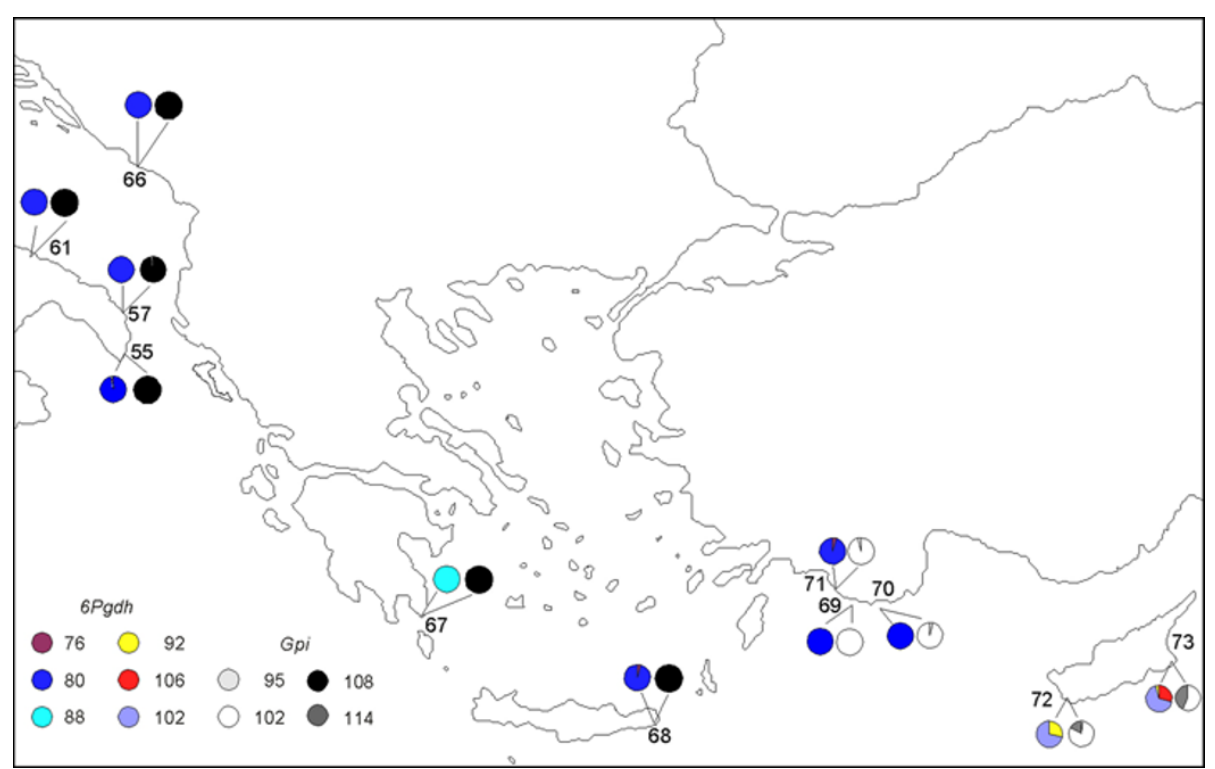

Figure 3 Geographic variation of allele frequencies at loci 6Pgdh and Gpi in allopatric populations of Ochthebius brevicollis steinbuehleri. For sample geographical origin see Table 1 .

ated from conspecific Sardinian populations by the sea, and low genetic differentiation was observed among these populations (eg, no significant $F_{\mathrm{ST}}$ values). These contrasting results could find a possible explanation in the dramatic changes the Mediterranean coasts have undergone since the last glaciations, as discussed by Urbanelli et al (1996). Therefore, the presence of frequent extinction and colonisation events have probably caused genetic differentiation by drift or allowed, by colonisation, the expansion of isolated populations without any 
Table 3 Scores assigned to individual characteristic alleles for the calculation of hybrid index scores (HIS) in the comparisons between Ochthebius quadricollis (A), Ochthebius sp. A (B) and O. brevicollis steinbuehleri $(\mathrm{C})$

\begin{tabular}{|c|c|c|c|c|}
\hline \multirow[t]{2}{*}{ Loci } & \multicolumn{2}{|c|}{ O. quadricollis (A) } & \multicolumn{2}{|c|}{ Ochthebius sp. A (B) } \\
\hline & Alleles & Score & Alleles & Score \\
\hline G3pdh & $90,100,110$ & +1 & 120 & -1 \\
\hline$M d h-1$ & 100,128 & +1 & 120 & -1 \\
\hline Idh-2 & $92,100,108$ & +1 & 96 & -1 \\
\hline $6 P g d h$ & $94,100,107$ & +1 & $92,98,104$ & -1 \\
\hline Aat-1 & 100 & +1 & 80,90 & -1 \\
\hline Pep-1 & 100 & +1 & 96 & -1 \\
\hline Gpi & $100,110,112,117$ & +1 & $93,98,104$ & -1 \\
\hline Pgm & $95,100,105$ & +1 & $108,110,114$ & -1 \\
\hline \multirow[t]{2}{*}{ Loci } & \multicolumn{2}{|c|}{ O. b. steinbuehleri $(\mathrm{C})$} & \multicolumn{2}{|c|}{ Ochthebius sp. A (B) } \\
\hline & Alleles & Score & Alleles & Score \\
\hline Idh-2 & 98 & +1 & 96 & -1 \\
\hline $6 P g d h$ & $76,80,88$ & +1 & $92,98,104$ & -1 \\
\hline Aat-1 & 100 & +1 & 80,90 & -1 \\
\hline Pep-1 & 100 & +1 & 96 & -1 \\
\hline Gpi & 108 & +1 & $93,98,104$ & -1 \\
\hline
\end{tabular}

significant differentiation. In fact, the processes of extinction and colonisation which should enhance the rate of genetic differentiation of populations may also have impeded the stochastic differentiation of populations, resulting, in turn, in an important source of gene flow (Slatkin 1981, 1987). The overall pattern of genetic variation within populations of O. quadricollis, Ochthebius sp. A and O. $b$. steinbuehleri thus appears to have been influenced by a complex interplay of isolation by distance, genetic drift and colonisation events, the effects of which played an important role in defining the levels of differentiation.

Another level of genetic divergence and reproductive isolation is represented by the species Ochthebius sp. A and O. b. steinbuehleri. Their gene pools appear fairly distinct (five loci were found to be diagnostic between species and the value of genetic distance, $D_{\text {Nei, }}$ was 0.61 ) in spite of the presence of some $F_{1}$ hybrids in a syntopic site. Nevertheless, these $F_{1}$ hybrids appear to have low fitness, for backcrosses or recombinant genotypes were never observed, and they only occur in a single site with

occasional sympatry. In fact, there is no stable coexistence between these two taxa, which showed a patchy distribution where their ranges overlap (Table 1 and Figures 2 and 3).

Full reproductive isolation has been achieved by $O$. quadricollis and Ochthebius sp. A. (eight diagnostic loci and $D_{N e i}=0.69$ ): no $\mathrm{F}_{1}$ or $\mathrm{F}_{\mathrm{n}}$ hybrids, nor backcrosses were found in the sympatric areas, but only introgressant genotypes. The absence of $\mathrm{F}_{1}$ hybrids between $O$. quadricollis and Ochthebius sp. A from all syntopic sites seems to indicate that effective reproductive barriers to gene exchange could have evolved where the two taxa met.

The study of the patterns of variation in sympatric areas would suggest that, whenever a stable coexistence took place between $O$. quadricollis and Ochthebius sp. A, the complete reproductive isolation was achieved. Conversely, when occasional syntopic sites occurred between Ochthebius sp. A and O. b. steinbuheleri (which seem to mutually exclude each other in the contact zone along the Adriatic coast) the reproductive isolation is incomplete even though the gene exchange was interrupted. Thus, if geographic isolation is central to the speciation process of the Ochthebius species (determining some degree of genetic divergence and reproductive isolation), sympatry could have influenced the completion of their reproductive isolation.

Researches have repeatedly shown that sympatric taxa are always more discriminating than allopatric ones. This is often attributed to natural selection, which strengthens premating isolation (sexual isolation) in response to maladaptive hybridisation following the secondary contact between two taxa (Coyne and Orr 1989, 1997; Howard, 1993; Butlin, 1995). The pattern of introgression between O. quadricollis and Ochthebius sp. A appears to somehow match this evolutionary scenario. The low frequency of introgression detected only in the syntopic sites, the existence of different patterns of introgression at the diagnostic loci, and the stability of the introgression surveyed during 4 years (Table 4) would suggest that some time in the past some gene exchange took place when $O$. quadricollis and Ochthebius sp. A came into secondary contact before having developed efficient reproductive isolation mechanisms. A further indication that introgressed specimens are not produced by an on-going hybridisation is the agreement of genotype frequencies with HardyWeinberg's expectations in the syntopic samples. How-

Table 4 Variation of the average number of specimens introgressed at loci Mdh-1, $6 P g d h, P g m$ and Gpi, at the sympatric sites from Campania, Basilicata and Calabria

\begin{tabular}{|c|c|c|c|c|c|c|c|c|c|c|c|c|c|c|c|c|}
\hline & \multicolumn{8}{|c|}{ Ochthebius quadricollis } & \multicolumn{8}{|c|}{ Ochthebius sp. A } \\
\hline & \multicolumn{2}{|c|}{$M d h-1$} & \multicolumn{2}{|c|}{ 6-Pgdh } & \multicolumn{2}{|c|}{ Pgm } & \multicolumn{2}{|c|}{ Gpi } & \multicolumn{2}{|c|}{$M d h-1$} & \multicolumn{2}{|c|}{$6-P g d h$} & \multicolumn{2}{|c|}{$P g m$} & \multicolumn{2}{|c|}{ Gpi } \\
\hline & $\begin{array}{c}\text { average } \\
\%\end{array}$ & $\begin{array}{c}\text { range } \\
\%\end{array}$ & $\%$ & $\begin{array}{c}\text { range } \\
\%\end{array}$ & $\begin{array}{c}\text { average } \\
\%\end{array}$ & $\begin{array}{c}\text { range } \\
\%\end{array}$ & $\begin{array}{c}\text { average } \\
\%\end{array}$ & $\begin{array}{c}\text { range } \\
\%\end{array}$ & $\begin{array}{c}\text { average } \\
\%\end{array}$ & $\begin{array}{c}\text { range } \\
\%\end{array}$ & $\begin{array}{c}\text { average } \\
\%\end{array}$ & $\begin{array}{c}\text { range } \\
\%\end{array}$ & $\begin{array}{c}\text { average } \\
\%\end{array}$ & $\begin{array}{c}\text { range } \\
\%\end{array}$ & $\begin{array}{c}\text { average } \\
\%\end{array}$ & $\begin{array}{c}\text { range } \\
\%\end{array}$ \\
\hline 1990 & 6.0 & $0-13.0$ & 16.0 & $0-26.3$ & - & - & 0.4 & $0-1.3$ & 3.4 & $0-11.4$ & 3.7 & $0-6.9$ & 1.9 & $0-4.9$ & 0.7 & $0-2.6$ \\
\hline 1991 & 4.3 & $0-14.3$ & 13.0 & $0-27.3$ & - & - & - & - & 2.4 & $0-9.1$ & 5.3 & $0-11.1$ & 2.6 & $0-5.6$ & 0.7 & $0-3.8$ \\
\hline 1992 & 9.1 & $0-36.1$ & 10.4 & $0-22.2$ & - & - & - & - & 1.2 & $0-4.2$ & 3.6 & $0-8.3$ & 6.2 & $0-3.0$ & - & - \\
\hline \multirow{2}{*}{1993} & 6.6 & $0-33.3$ & 12.2 & $0-27.6$ & - & - & - & - & 1.2 & $0-5.0$ & 3.0 & $0-6.3$ & 4.7 & $0-3.1$ & 0.6 & $0-4.2$ \\
\hline & \multicolumn{2}{|c|}{$\begin{array}{c}\chi^{2}=3.2 \\
\text { NS }\end{array}$} & \multicolumn{2}{|c|}{$\begin{array}{c}\chi^{2}=2.94 \\
\text { NS }\end{array}$} & \multicolumn{2}{|c|}{$\begin{array}{c}\chi^{2}=0.0 \\
\text { NS }\end{array}$} & \multicolumn{2}{|c|}{$\begin{array}{c}\chi^{2}=2.38 \\
\text { NS }\end{array}$} & \multicolumn{2}{|c|}{$\begin{array}{c}\chi^{2}=3.64 \\
\text { NS }\end{array}$} & \multicolumn{2}{|c|}{$\begin{array}{c}\chi^{2}=0.99 \\
\text { NS }\end{array}$} & \multicolumn{2}{|c|}{$\begin{array}{c}\chi^{2}=8.51 \\
\text { NS }\end{array}$} & \multicolumn{2}{|c|}{$\begin{array}{c}\chi^{2}=1.16 \\
\text { NS }\end{array}$} \\
\hline
\end{tabular}



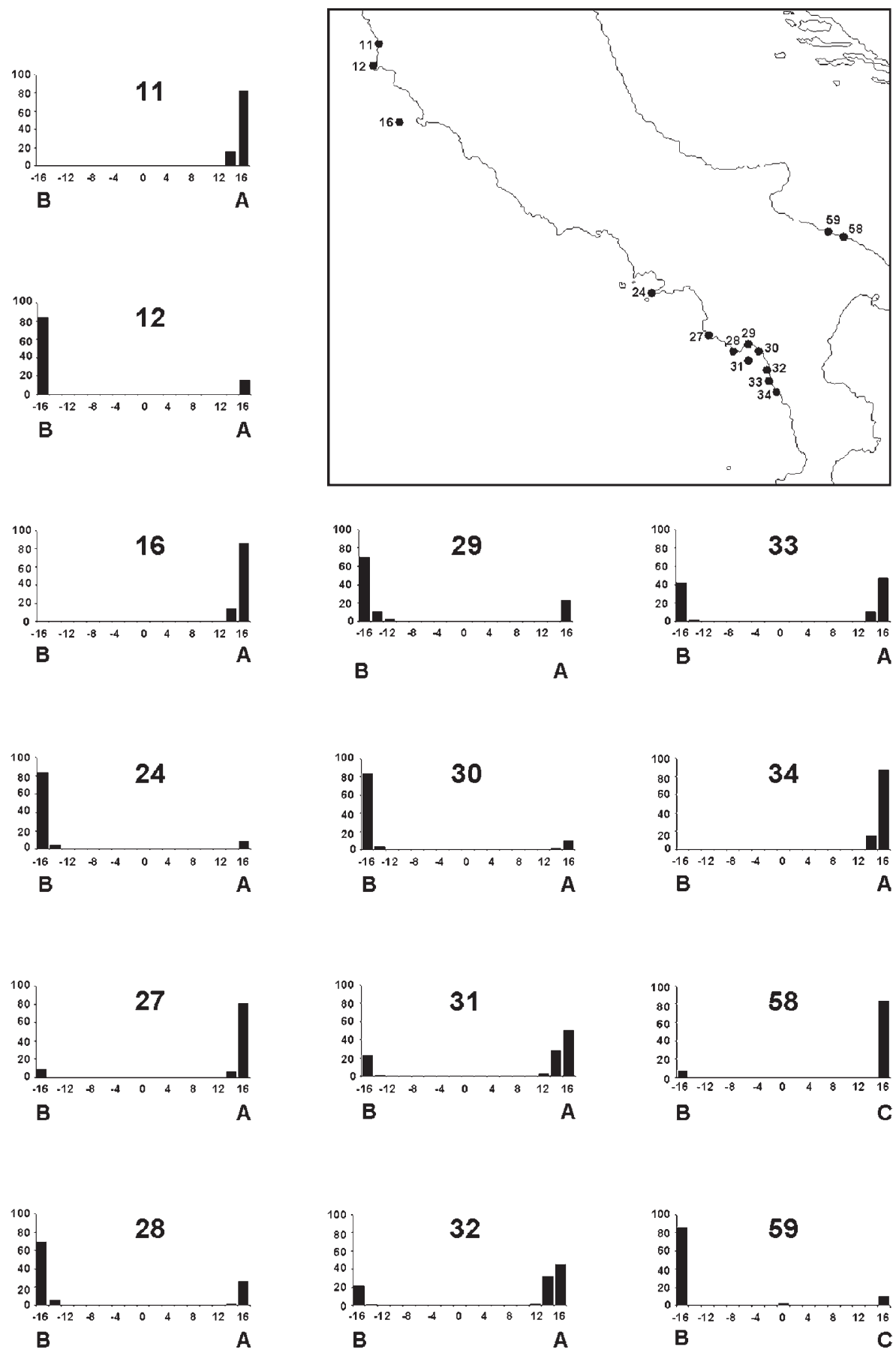

Figure 4 Distribution of individual hybrid index scores (HIS), based on eight diagnostic loci in some sympatric sites between Ochthebius quadricollis (A) and Ochthebius sp. A (B) from Tuscany, Campania, Basilicata and Calabria; between Ochthebius sp. A (B) and O. brevicollis steinbuehleri (C) from Apulia.

ever, research is being conducted into the assortative mating between sympatric and allopatric populations to assess whether natural selection, strengthening of mate discrimination, or other causes are responsible for the evolution of reproductive isolation between Coleoptera species. In fact both competitive exclusion and ecological character displacement could also explain the evolution of reproductive isolation in sympatry (Zouros and D'Entremont, 1980; Templeton, 1981; Grant and Grant,
1995; Rundle and Schluter, 1998). If there is a clear-cut ecological differentiation at the time of the secondary contact, the competition for common resources between the two populations may lead to character displacement. However, the explanations invoking ecological differentiation do not require any hybridisation to happen, while for the natural selection hypothesis hybridisation and the production of hybrids are a necessary step (Kulathinal and Singh, 2000). 


\section{Acknowledgements}

Special thanks go to Dr Pina Sallicandro and Dr Emanuele De Vito for their unfailing dedication to field and laboratory work. The authors are thankful to Prof Bullini, Prof Nascetti for the helpful comments and to Dr Veronica Della Rosa, Dr Monica Brocco and Mrs Alessandra Spanò for their invaluable technical assistance. The research was carried out with grants from the Ministero Università e Ricerca Scientifica e Tecnologica (MURST).

\section{References}

Beier M (1956). Über körperbau und lebensweise von Ochthebius quadricollis steinbuehleri Rtt. Und O. adriaticus Rtt. (Col. Hydroph. Hydraen.). Thalassia Jugoslavica 1: 193-242.

Bert TM, Harrison RG (1988). Hybridization in western Atlantic stone crabs (genus Menippe): evolutionary history and ecological influence species interactions. Evolution 42: 528-544.

Bush GI, Howard DJ (1986). Allopatric and non-allopatric speciation; assumptions and evidence. In: Karlin S, Nevo (eds) Evolutionary Processes and Theory, Academic Press Inc: San Diego. pp 411-438.

Butlin RK (1995). Reinforcement: an idea evolving. Trends Ecol Evol 10: 432-434.

Coyne J, Orr HA (1989). Patterns of speciation in Drosophila. Evolution 43: 362-381.

Coyne J, Orr HA (1997). Patterns of speciation in Drosophila' revisited. Evolution 51: 295-303.

Feder JL, Opp SB, Wlazlo B, Berlocher SH (1997). Selective maintenance of allozyme differences among sympatric host races of the apple maggot fly. Proc Natl Acad Sci USA 94: 1141711421.

Grant PR, Grant BR (1995). Speciation and hybridisation in island birds. Phil Trans $R$ Soc Lond B Biol Sci 351: 765-772.

Harrison RG (1990). Hybrid zones: windows on evolutionary process. In: Futuyma D, Antonovics J (eds) Oxford Surveys in Evolutionary Biology, Vol. 7, Oxford University Press: Oxford. pp 69-128.

Howard DJ (1993). Reinforcement: origin, dynamics and fate of an evolutionary hypothesis. In: Harrison RG (ed) Hybrid Zones and Evolutionary Process, Oxford University Press: Oxford. pp 46-69.

Koehn RK, Eanes WF (1978). Molecular structure and protein variation within and among populations. Evol Biol 11: 39-100.

Kulathinal RJ, Singh RS (2000). A biogeographic genetic approach for testing the role of reinforcement: the case of Dro-

Mayr E (1963). Animal Species and Evolution. The Bellknap Press of Harvard University Press: Cambridge, Massachusetts.

Nei M (1978). Estimation of average eterozygosity and genetics distance from a small number of individuals. Genetics 89: 583-590.

Nei M (1987). Molecular Evolutionary Genetics. Columbia University Press: New York.

Nei M, Chesser RK (1983). Estimation of fixation indices and genetic diversities. Ann Hum Genet 47: 253-259.

Patton JL, Hafner JC, Hafner MS, Smith MF (1979). Hybrid zones in Thomomys bottae pocket gophers. Genetic, phenetic and ecologic concordance patterns. Evolution 33: 860-876.

Rice WR, Hostert EE (1993). Laboratory experiments on speciations: what have we learned in 40 years? Evolution 47: 16371653.

Rundle HD, Schluter D (1998). Reinforcement of stickleback mate preferences: sympatry breeds contempt. Evolution 52: 200-208.

Sage RD, Contreras JR, Roig VG, Patton JL (1986). Genetic variation in the South American burrowing rodents of the genus Ctenomys (Rodentia, Ctenomidae). Z Saugetier 51: 158-172.

Slatkin M (1981). Estimating levels of gene flow in natural populations. Genetics 99: 323-335.

Slatkin M (1985). Gene flow in natural populations. Ann Rev Ecol Syst 16: 393-430.

Slatkin M (1987). Gene flow and the geographic structure of natural population. Science 236: 787-792.

Sokal RR, Rohlf FJ (1981). Biometry. 2nd edn. Freeman: San Francisco.

Templeton AR (1981). Mechanism of speciation: a population genetic approach. Ann Rev Ecol Syst 12: 23-48.

Urbanelli S, Sallicandro P, De Vito E, Colonnelli E, Bullini L (1996). Molecular reexamination of the taxonomy of Ochthebius (Calobius) (Coleoptera: Hydraenidae) from the Mediterranean and Macaronesian regions. Ann Entomol Soc Am 89: 623-636.

Weir BS, Cockerham CC (1984). Estimating F-statistics for the analysis of population structure. Evolution 38: 1358-1370.

Wright S (1931). Evolution in Mendelian populations. Genetics 16: $97-159$

Wright S (1951). The genetical structure of populations. Ann Eugen 15: 323-354.

Zouros E, D'entremond CJ (1980). Sexual isolation among populations of Drosophila majavensis: response to pressure from a related species. Evolution 34: 421-430. 